\title{
Readiness levels of Industry 4.0 technologies applied to aircraft manufacturing - a review, challenges and trends
}

\author{
Gabriel Consoni Zutin ${ }^{1}$. Gustavo Franco Barbosa ${ }^{1}$. Pedro Cabegi de Barros ${ }^{1}$ - Eduardo Bizeli Tiburtino ${ }^{2}$. \\ Frederico Leoni Franco Kawano ${ }^{3}$. Sidney Bruce Shiki ${ }^{1}$
}

Received: 6 November 2021 / Accepted: 14 January 2022 / Published online: 8 February 2022

(c) The Author(s), under exclusive licence to Springer-Verlag London Ltd., part of Springer Nature 2022

\begin{abstract}
The present paper provides an overview of the state-of-the-art research, outlining the applications of the Industry 4.0 (I4.0) technologies on the aircraft manufacturing sector and their maturity state based on the technology readiness level (TRL) scale. A literature review has been conducted for the identification, selection, and evaluation of the published research. A total of 57 papers extracted from the two most relevant scientific databases for the area (Web of Science and Scopus), from 2010 to March 2021, were analysed and summarized. The research, analysis, and evaluation of these papers has provided an outlook of how the aircraft manufacturing industry is inserted into the I4.0 context, based on a classification of the I4.0 technologies maturity for this industrial branch. Then, a survey was performed with 12 specialists from 5 different aircraft manufacturing companies aiming to report the practical point-of-view in this area. Thus, this paper highlights and discusses the gaps found in the literature related to the I4.0 technologies applied to aircraft manufacturing and their main useful implications not only from the academic point-of-view but also from competitive business aspects, providing recommendations for industrial managers, engineers, and stakeholders. Finally, this paper proposes new opportunities and challenges for future research.
\end{abstract}

Keywords Industry $4.0 \cdot$ Aircraft manufacturing $\cdot$ Technology readiness level

Gustavo Franco Barbosa

gustavofb1974@hotmail.com

Gabriel Consoni Zutin

gabrielcon.zutin@gmail.com

Pedro Cabegi de Barros

pedrocabegi@gmail.com

Eduardo Bizeli Tiburtino

edu.bizeli@gmail.com

Frederico Leoni Franco Kawano

frederico.kawano@embraer.com.br

Sidney Bruce Shiki

bruce@ufscar.br

1 Mechanical Engineering Department, Federal University of Sao Carlos, Sao Carlos, Brazil

2 Department of Production Engineering, Federal University of Sao Carlos, Sao Carlos, Brazil

3 Brazilian Aeronautics Enterprise Co. (EMBRAER), Gaviao Peixoto, Brazil

\section{Introduction}

The modern manufacturing industry has been strongly affected by the globalized market, which looks for a combination of increased productivity, high quality of the products, flexibility, reduction of the product life cycle, and digitalization of the processes [1,2].

Inside this context, the Industry 4.0 (I4.0) represents a new technological era that comprises the use of Internetbased technologies, focused on intelligent systems that continuously acquire and process data exchanging information between machines and systems $[3,4]$. It is also described as the Industry Internet of things (IoT), which connects smart devices to monitor the manufacturing processes [5, 6]. These networked interconnections of devices allow the communication among individuals and technologies in cyber-physical systems (CPS) [7]. Thus, the scope of I4.0 includes technologies of artificial intelligence, simulation, automation, robotics, IoT, data collection systems, sensors, cloud, augmented reality, additive manufacturing, among others [8].

Faced with this new industrial revolution, aircraft manufacturers have been looking at these modern technologies 
to maximize competitiveness. In this sense, the increase of digital technologies availability has led the aircraft builders to focus on prospecting, research and development to provide conditions to make their manufacturing processes more intelligent [9]. So, there has been observed a greater specialization of the technologies suppliers that look for establishing partnership agreements with aircraft companies in order to share the development costs and take competitive advantages of that [10]. This is especially important since this branch of industry is one of the most important manufacturing sectors of high value-added durable goods [11].

Thus, several studies show an approach between I 4.0 technologies and their use in the aircraft sector for its business strategy, looking for a boost of efficiency, reliability, and innovation when applied into the manufacturing processes $[9,12,13]$. Also, the implementation of the I4.0 technologies on the aircraft production shop floor has been demonstrated to be a strategic initiative to change the company mentality in terms of advanced manufacturing gains, enabling a greater level of automatization, efficiency, and flexibility to be achieved in the overall process [5, 14-16]. Faced with that, aircraft manufacturers have looked to keep updated to be competitive in the global market to develop aircrafts faster, cheaper, and better. To ensure that, the way is to embrace the new digital tools of I4.0 on their processes [17].

However, aircraft manufacturing is a kind of industry where the costs related to the development of new products are extremely high compared to other industrial segments. Because of that, the adoption of digital technologies of I4.0 may appear expensive in the short term. However, as the technologies help aircraft manufacturers avoid mistakes and wastes that increase product development costs, the I4.0 technologies will be economically feasible in the long term by saving time and money [18]. For this reason, the readiness levels of the I4.0 technologies to be applied on processes should be dealt with extreme care, making sure that technologies with a significant level of maturity for this specific industrial sector will provide a fast return of investment. In this way, a classification of the technology's maturity becomes necessary to evaluate the feasibility of application on aircraft manufacturing processes. Thereby, it is necessary to use methods such as TRLs (technology readiness levels), which assess the level of maturity of a given technology during its acquisition phase [19].

Thus, this scientific contribution aims to highlight the state-of-the-art research about the manufacturing industry and its insertion into the I4.0 context, based on the classification of the I4.0 technologies maturity levels for this particular industrial branch. This paper presents and discusses the most applied I4.0 technologies on the aircraft business, their levels of maturity, the gaps found in the academic literature, a critical analysis, and their relevant impacts, limits, and opportunities to the aeronautical sector.

\section{Theoretical background}

\subsection{Industry 4.0}

The fourth Industrial Revolution - or Industry 4.0 - came to change and update modern factories once and for all, causing a technological revolution in terms of strategies, organization, business models, value and supply chains, processes, products, skills, and ownership relationships of companies. This update is driven changing operative framework conditions triggered by social, economic, and political changes as well as by an extensive technological-push brought by new communication and manufacturing techniques [20].

These factors significantly impact business and society, and such opportunities must be managed and administered correctly [21]. This revolution is based on four fundamental technological pillars: the IoT, industrial IoT, cloud-based manufacturing, and intelligent manufacturing, which helps to transform the fully digitalized manufacturing process into smart factories [22, 23]. The nine technologies of Industry 4.0 will be able to integrate areas and cells of a company that were previously isolated in a continuous, automated, and optimized production flow, leading to greater efficiency between prudential relationships, suppliers, manufacturers, and customers, as well as relationship between man and machine [24]. The evolution and incorporation of the I4.0 technologies can also be an important factor on increasing the sustainability of the manufacturing industry $[25,26]$.

\subsection{TRL}

TRL is a system used to estimate the level of maturity of a given technology, popularly known thanks to NASA (National Aeronautics and Space Administration) and the United States Department of Defence. TRL is based on a scale of 1 to 9 , with 9 being the most mature technology and 1 a newly created technology. The use of TRLs allows uniform and consistent discussions on technical maturity in different types of technology [27]. In 1989, the concept of maturity levels was starting to be introduced. The results of an opportunity-driven technology model must be evaluated appropriately because they cannot necessarily prove their viability on a space mission at the time of development, and that was the main function of the maturity level scale. The need for such a classification emerged strongly when the series of successful programs - Explorers, Pioneers, Mariners, and Apollo-generated a vast inventory of new technologies. This type of work was called TRL 2 years later, in 1991, when NASA used the TRL scale in its Integrated Technology Plan for the Civil Space Program, and the scale defined levels from 1 to 9 [28]. John C. Mankins defined each level that included 
several examples of technologies at certain levels in the year 1995 [29]. The levels were as follows:

- Level 1 - Basic principles observed and reported

- Level 2 - Concept of technology and/or formulated application

- Level 3 - Critical analytical and experimental function and/or characteristic proof of concept

- Level 4 - Validation of component and/or test plate in a laboratory environment

- Level 5 - Validation of component and/or test plate in relevant environment

- Level 6 - System/subsystem model or prototype demonstration in a relevant environment (soil or space)

- Level 7 - Demonstration of a system prototype in a space environment

- Level 8 - Real system completed and "qualified for flight" through testing and demonstration (ground or space)

- Level 9 - Real system "proven in-flight" through successful mission operations

Levels 1 and 2 are part of development and research. From level 3 to 6 , this is where the tests are, whether by simulation, in the laboratory, and even the test of the prototype in a situation close to the real one. Finally, levels 7,8 , and 9 seek to subject the prototype to real operating situations, reaching the last phase of validation of the new technology [28]. Although TRL invention was at the end of the last century, its use and application are gaining strength today with the fourth industrial revolution and the advancement of little-explored technologies. Its objective, in addition to classifying the maturity of the technology, is also to assist in risk analysis, resource management and also to point out improvement possibilities that in the future may cause a decrease in manufacturing costs or even capital savings due to the reduction of expense to correct problems [30].

Therefore, in the coming decades, significant efficiency gains are expected, mainly through digital integration and manufacturing processes' intelligence. Concepts like IoT, cloud-based manufacturing, and digital manufacturing meet these requirements. But there are problems in determining its state of development concerning the vision of Industry 4.0 and, consequently, fail to identify specific fields of action, programs, and projects. To overcome the growing uncertainty and dissatisfaction in manufacturing companies regarding the idea of Industry 4.0, new methods and tools, such as TRL, are needed to provide guidance and support to align business and operations strategies [5].

\subsection{Industry 4.0 and aircraft manufacturing}

It is necessary not only to apply the combination of digital technology to the aircraft manufacturing and design process but also to emphasize the collaboration between design and manufacturing. In order to reach these goals, the decentralized design in real-time, and the information of manufacturing would be collected, optimized, and integrated by an intelligent control system, to better meet the aircraft design and manufacturing processes, in order to optimize the entire product [31].

Industry 4.0 features several technologies, such as networking, availability of large volumes of data, customized production capacity, interconnected microsensor networks, intelligent visualization of information in remote operations, and automation, are examples of suitable technologies not only in common factories but also in aeronautics. Technologies such as additive manufacturing and augmented reality are likely to be the main participants in aircraft maintenance and manufacturing strategies in the future, given the potential of both [32].

\section{Methodology}

In this paper, a literature review was performed in order to map the academic production in the last 10 years. With this method, it is possible to locate, select, and evaluate the literature's contributions to the researched topic [33]. The advantages of this kind of study are that it guarantees a structured, repeatable, and scientific process that allows existing information to be synthesized in a rigorous and objective process [24].

This paper follows the best practices in literature review, consisting of five steps [24]. The specific phases followed were as follows: (1) formulating the research question; (2) locating the studies; (3) selecting and evaluating relevant studies; (4) analyzing and synthesizing the findings; (5) reporting the results.

\subsection{Phase 1: research questions}

This phase identifies the scope, purpose, and objectives, and these are reflected in the general research question (RQ):

$\mathrm{RQ}$. Analysis of the state-of-the-art literature on the relationships between aircraft manufacturing, I4.0, and TRL. This general question is broken down into three specific questions:

1. Which I4.0 technologies are being applied in aircraft manufacturing?

2. How mature are the I 4.0 technologies in the aircraft manufacturing sector?

3. What gaps exist in the literature that relates digital manufacturing and aircraft industry, and in what direction should future research go in? 
Fig. 1 I4.0, TRL, and aircraft manufacturing relationship: developed by the authors

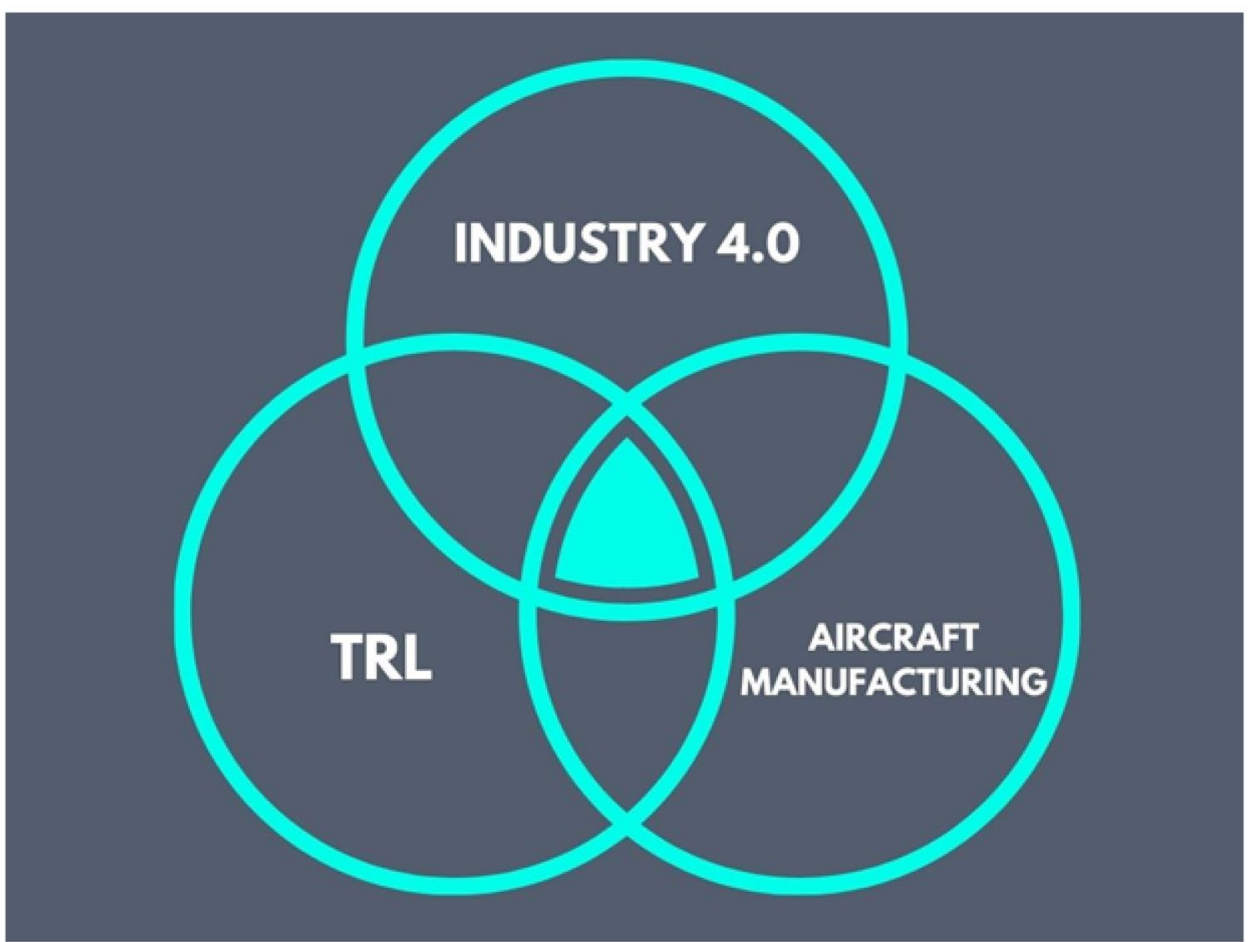

\subsection{Phase 2: locating the studies}

This step consists of finding papers and studies related to the research question formulated in the previous phase. The key of this step is to choose the correct keywords and databases because if the selected literature is inadequate or irrelevant, the contribution of the following phases will be wrong [24].

The choice of the database must correspond to the study area. It is essential using more than one database to locate as many relevant studies as possible and reduces any potential publication bias [33]. In this research, the most relevant databases in the study area have been used as search engines: Web of Science (WoS) and Scopus which are generally used in literature reviews related to engineering.

In this case, the research's objective is to relate aircraft manufacturing, I4.0, and TRL. Search chains were, therefore, specifically designed to locate documents in this intersection area (see Fig. 1).

The search strings were selected, combining keywords for each of these areas. The search keywords must be
Table 1 Keywords used in this research

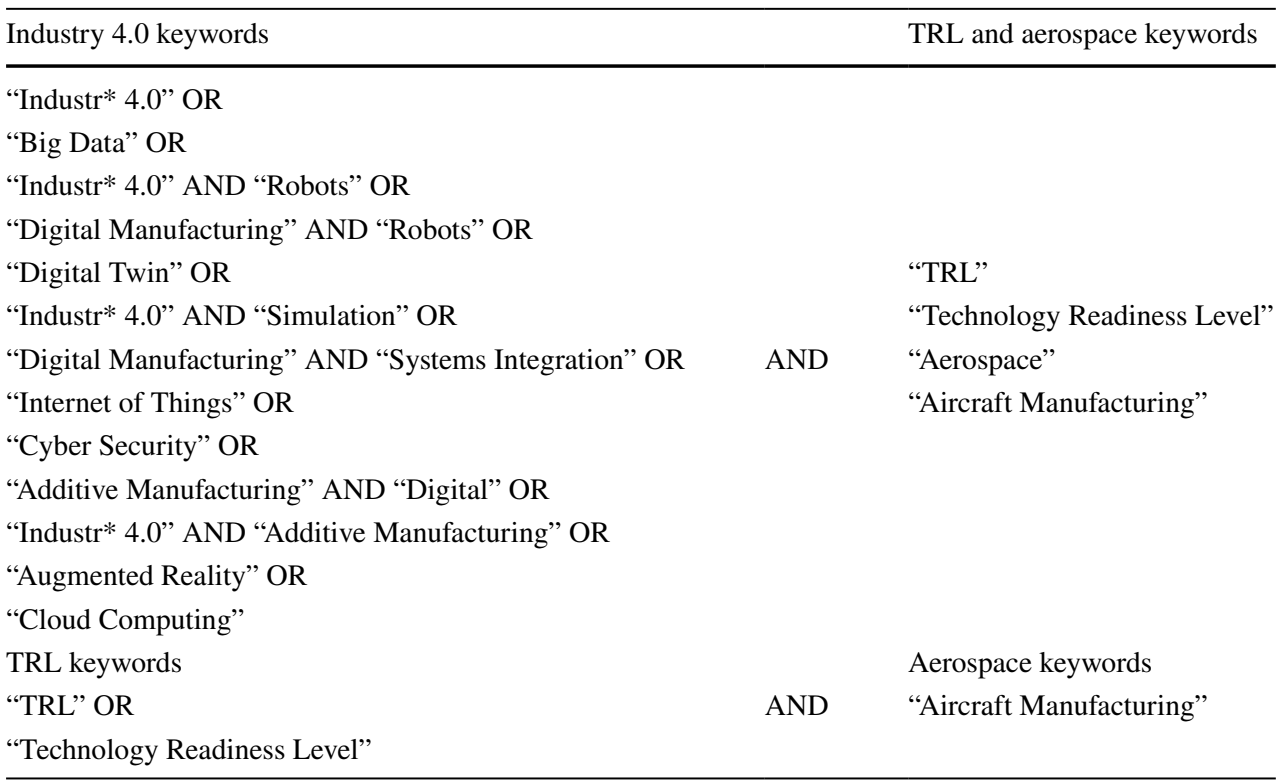

Source: Developed by the authors 
Table 2 Details of inclusion and exclusion criteria

\begin{tabular}{|c|c|c|c|}
\hline Criteria type & Criteria & Code & Criteria detail \\
\hline \multirow[t]{6}{*}{ Exclusion } & Search engines reason & SER & SER (1): The paper has a title and abstract in English, but does not have the full text \\
\hline & & & $\begin{array}{l}\text { SER (2): The article does not come from an academic journal, that is, it originates from a book, a } \\
\text { book section, or a conference proceeding }\end{array}$ \\
\hline & Not full text & NFT & The paper does not have available text to be assessed \\
\hline & Time range & TRC & The article was not published within the defined time range: as of 2009 \\
\hline & Non-related & NR & $\begin{array}{l}\text { NR: The article does not relate aircraft manufacturing or its activities to the main technologies of } \\
\text { Industry } 4.0 \text { adopted in this review }\end{array}$ \\
\hline & Loosely related & LR & $\begin{array}{l}\text { The article was loosely related aircraft manufacturing with Industry } 4.0 \text {, that is, the article does not } \\
\text { express discussion or results of the technologies application }\end{array}$ \\
\hline \multirow[t]{3}{*}{ Inclusion } & Partially related & PR & $\begin{array}{l}\text { PR (1): The article generically addresses the subject of Industry 4.0, focusing on integration with } \\
\text { one or a few elements of the aircraft manufacturing }\end{array}$ \\
\hline & & & $\begin{array}{l}\text { PR (2): Integration of aircraft manufacturing with Industry } 4.0 \text { frames only one of several research } \\
\text { objectives, or some extracts of the article }\end{array}$ \\
\hline & Closely related & $\mathrm{CR}$ & $\begin{array}{l}\text { The research focus of a paper clearly and strictly addresses the integration of aircraft } \\
\text { manufacturing with Industry } 4.0 \text { and its capabilities }\end{array}$ \\
\hline
\end{tabular}

Source: Developed by the authors

broad enough not to restrict the number of studies but specific enough to find only studies related to the topic. Therefore, the research keywords were determined jointly by the researcher, using each technology of I4.0 and related terms.
Using logical and Boolean operators, the search string design aims to ensure that the studies contain at least one of the keywords for each of two blocks of three (aircraft manufacturing, I4.0, TRL) in the title, abstract, or keywords or more broadly in the topic (in the case of WoS; title, abstract,

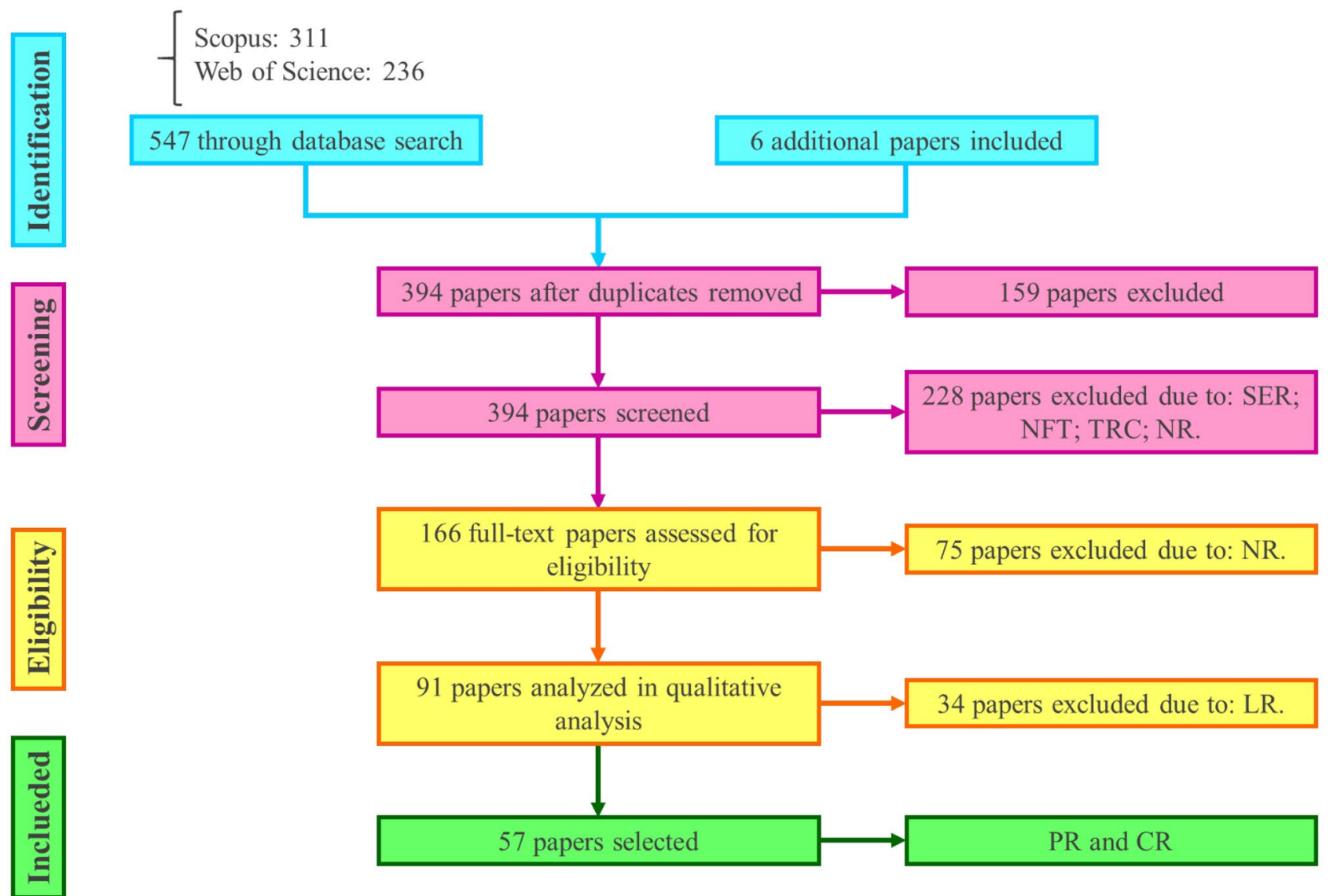

Fig. 2 PRISMA flowchart of the systematic review: developed by the authors 
Table 3 Maturity levels and classification criteria

\begin{tabular}{|c|c|c|}
\hline \multicolumn{3}{|c|}{ TECHNOLOGY READINESS LEVEL } \\
\hline PHASE & $\begin{array}{l}\text { TR } \\
\mathbf{L}\end{array}$ & STATE OF DEVELOPMENT \\
\hline \multirow{3}{*}{$\begin{array}{l}\text { PHASE 3: PRODUCTION } \\
\text { IMPLEMENTATION }\end{array}$} & 9 & Actual technology qualified through successful mission operations. \\
\hline & 8 & $\begin{array}{l}\text { Actual technology completed and qualified through test and } \\
\text { demonstration. }\end{array}$ \\
\hline & 7 & Technology prototype demonstration in an operational environment. \\
\hline \multirow{2}{*}{$\begin{array}{l}\text { PHASE 2: PRE- } \\
\text { PRODUCTION }\end{array}$} & 6 & $\begin{array}{c}\text { Technology model or prototype demonstration in a relevant } \\
\text { environment. }\end{array}$ \\
\hline & 5 & Technology basic validation in a relevant environment. \\
\hline \multirow{4}{*}{$\begin{array}{l}\text { PHASE 1: TECHNOLOGY } \\
\text { ASSESSMENT PROVING }\end{array}$} & 4 & Technology basic validation in a laboratory environment. \\
\hline & 3 & $\begin{array}{l}\text { Analytical and experimental critical function and/or characteristic } \\
\text { proof-of-concept. }\end{array}$ \\
\hline & 2 & Technology concept and/or application formulated. \\
\hline & 1 & Basic principles observed and reported. \\
\hline
\end{tabular}

Source: Developed by the authors

author's keywords, expanded keywords). This strategy relating two blocks at a time was used to guarantee a sufficient number of articles since there are not enough studies that bring together the three blocks [24]. The search words and search strings used in each of the databases are shown in Table 1.

A total of 547 papers have been identified in this step. Two hundred thirty-six have been identified in WoS and 311 in Scopus.

\subsection{Phase 3: selecting and evaluating the studies}

The phase 3 objective is to discard any studies that are not relevant. The first step in this phase is defining some criteria. The criteria established in this phase must be explicit and demonstrate the completeness of the resulting review [24]. That establishes the studies that should be considered in the review (inclusion criteria) and those that should be discarded without further analysis (exclusion criteria) [33]. The application of these criteria eliminates articles that clearly do not belong to the review, and those that could be included are selected. In this research, the search was limited to works published in English until March 2021, and 169 duplicate documents were excluded, resulting in 388 documents remaining.

The next procedure comprised applying the "Preferred Reporting Items for Systematic Review and Meta-Analysis" (PRISMA) [34] approach to the following activities: identification, screening, eligibility, and inclusion. The PRISMA flow diagram has been used to draw up this figure [33]. The flow diagram depicts the flow of information through the review phases, mapping out the number of records identified, included, and excluded and the reasons for their exclusions. The first five exclusion criteria 


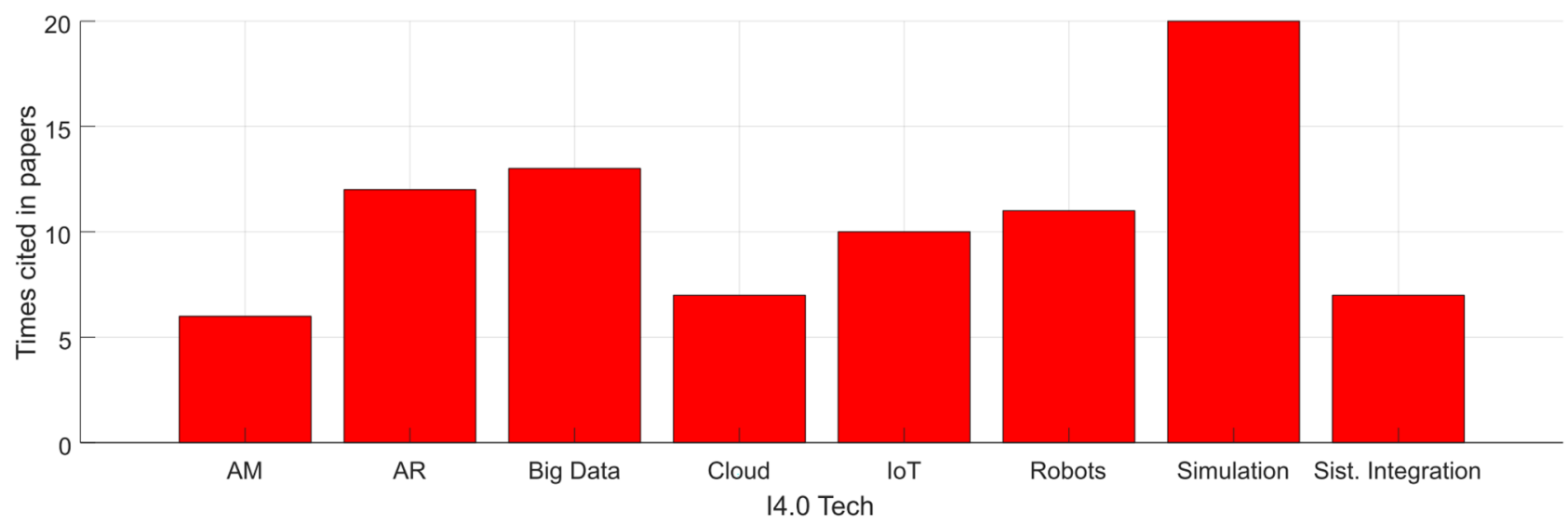

Fig. 3 Number of mentioned papers per technology

(SER, NFT, TRC, NRP, and NR) presented in Table 2 were applied to the 388 identified articles in a first screening process.

As a result, we excluded 228 documents. From a reading of the abstracts, keywords, titles, and conclusions, the remaining exclusion criteria in Table 2 (NR and LR) were applied, resulting in the additional exclusion of 75 articles. From the complete reading of the selected articles, were excluded 34 articles that was not possible to assess the maturity level of the applied technologies.

Accordingly, a final set of 51 articles was obtained. 6 new articles were detected as a result of examining the references used in the articles selected in step 3 (forward search) and the references in these papers (back search/snowballing effect) and added to those identified in direct database searches, with a final total of 57 articles eventually obtained.

These articles were eligible for full reading and possible inclusion in the systematic review. The details regarding the number of articles excluded due to each criterion in Table 2 are shown in Fig. 2.

\subsection{Phase 4: analyzing and synthesizing the findings}

The next step has been to review and analyze each of the selected articles by reading them in their entirety. Predefined structured coding of the information has been done in this phase in order to mine the relevant details in each of

Table 4 Analysis of papers dealing with multiple I4.0 technologies

\begin{tabular}{|c|c|c|c|c|c|c|c|c|c|}
\hline & & I 4.0 & inolo & & & & & & \\
\hline & & AM & AR & Big Data & Cloud & IoT & Robots & Simulation & Sist. integration \\
\hline Authors & Jia et al. [35] & & & & & & & $\mathrm{X}$ & $\mathrm{X}$ \\
\hline & Wang et al. [36] & & & $\mathrm{X}$ & $X$ & $\mathrm{X}$ & & & \\
\hline & Song et al. [37] & & & $\mathrm{X}$ & & & $\mathrm{X}$ & & \\
\hline & Druout et al. [38] & & & $\mathrm{X}$ & & $\mathrm{X}$ & $\mathrm{X}$ & & $\mathrm{X}$ \\
\hline & Guo et al. [39] & & & $\mathrm{X}$ & $\mathrm{X}$ & $\mathrm{X}$ & $\mathrm{X}$ & $\mathrm{X}$ & $\mathrm{X}$ \\
\hline & Guo et al. [40] & & & $\mathrm{X}$ & $X$ & $\mathrm{X}$ & & & $\mathrm{X}$ \\
\hline & Ismail et al. [41] & & & & $\mathrm{X}$ & $\mathrm{X}$ & & & \\
\hline & Korchagin et al. [42] & & & $\mathrm{X}$ & $\mathrm{X}$ & $\mathrm{X}$ & & $X$ & $\mathrm{X}$ \\
\hline & Luxenburger et al. [43] & & $\mathrm{X}$ & & & & $\mathrm{X}$ & & \\
\hline & Tao and Qi [44] & & & $\mathrm{X}$ & & & & $X$ & \\
\hline & Liang et al. [45] & & & $\mathrm{X}$ & & $\mathrm{X}$ & & $X$ & $\mathrm{X}$ \\
\hline & Miller et al. [46] & $\mathrm{X}$ & $\mathrm{X}$ & & & & & & \\
\hline & Xin et al. [47] & & & $\mathrm{X}$ & & & $\mathrm{X}$ & $\mathrm{X}$ & \\
\hline & Zhang et al. $[48,49]$ & & & $\mathrm{X}$ & & & $\mathrm{X}$ & $X$ & \\
\hline & Total & 1 & 2 & 10 & 5 & 7 & 6 & 7 & 6 \\
\hline
\end{tabular}

Source: Developed by the authors 
Fig. 4 Evolution of papers publication along the years

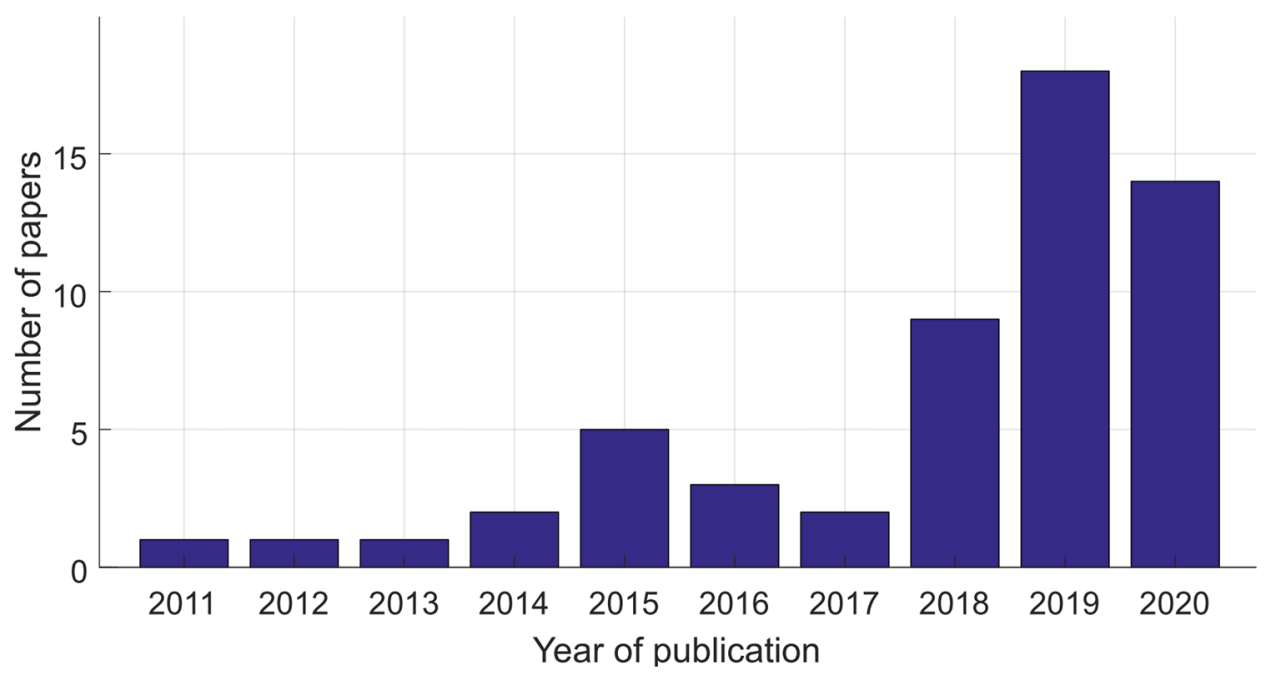

the studies and enable researcher involvement in this process [24].

During the article analyzing process, a database was designed in a spreadsheet containing the main ideas, objectives, title, author, journal, year of publication, methodology, sector, journal quality index and impact and number of times the paper has been cited. Subsequently to this stage, the maturity of each technology in Industry 4.0 will be classified in the aeronautical industry, using the three phases of development: technology assessment proving (experimental), pre-production, and production implementation (operational). The classification criteria, as well as were defined according to Table 3 .

At the end of this phase, experts from the aeronautical industry will be consulted to classify the technologies based on their professional knowledge. The results were compared with the classification made only by the evaluation of the articles.

\subsection{Phase 5: reporting the results}

The last step consists of reporting the results of the analysis and the synthesis of the literature. For this, all the information gathered from the articles was combined, and a descriptive overview of the reviewed literature sought, with a discussion of the findings and the identification of any extant research gaps and future research lines. The results of this step are given in Sect. 4.

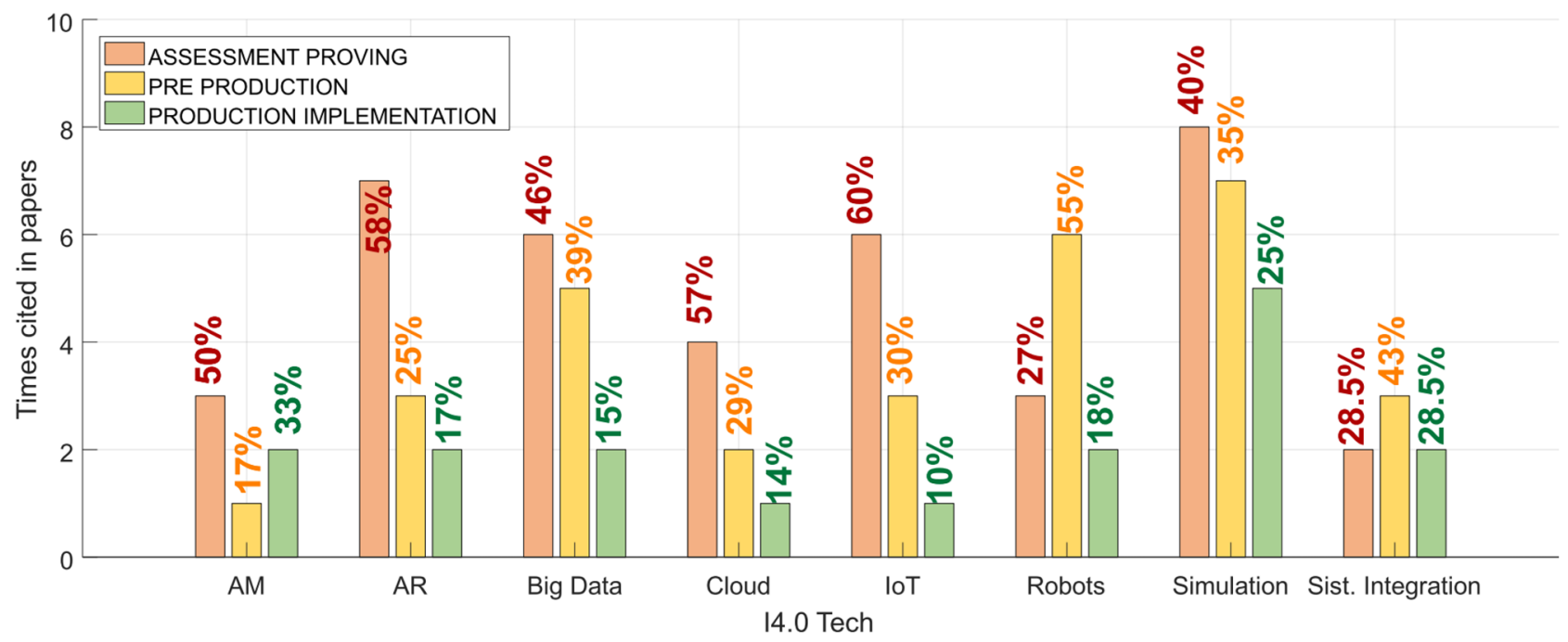

Fig. 5 Paper's classification based on the maturity levels per technology 
Table 5 Classification of the literature according to the I4.0 technology employed/developed in the research and with respect to the TRL phase

\begin{tabular}{|c|c|c|c|}
\hline I4.0 TECH. & Phase & References & Amount \\
\hline \multirow{3}{*}{$\mathrm{AM}$} & 1 & Jennet et al. [60], Manda et al. [65], Miller et al. [46] & 3 \\
\hline & 2 & Khajavi et al. [59] & 1 \\
\hline & 3 & Najmon et al. [71], Romero and Vieira [80] & 2 \\
\hline \multirow{3}{*}{$\mathrm{AR}$} & 1 & $\begin{array}{l}\text { Marzano et al. [68], Miller et al. [46], Ottogalli et al. [73], Ou [74], } \\
\text { Regenbrecht et al. [76], Rice et al. [78], Safi et al. [82] }\end{array}$ & 7 \\
\hline & 2 & Gupta et al. [58], Luxenburger et al. [43], Mayrhofer et al. [70] & 3 \\
\hline & 3 & Frigo et al. [9], Bottani and Vignali [54] & 2 \\
\hline \multirow{3}{*}{ Big Data } & 1 & $\begin{array}{l}\text { Druout et al. [38], Ruiz et al. [81], Song et al. [37], Tao and Qi [44], } \\
\text { Wang et al. [36], Xia et al. [86] }\end{array}$ & 6 \\
\hline & 2 & $\begin{array}{l}\text { Guo et al. [39], Guo et al. [40], Liang et al. [45], Xin et al. [47], Zhang } \\
\text { et al. [48] }\end{array}$ & 5 \\
\hline & 3 & Korchagin et al. [42], Airbus [50] & 2 \\
\hline \multirow{3}{*}{ Cloud } & 1 & Ismail et al. [41], Lv [64], Um et al. [85], Wang et al. [36] & 4 \\
\hline & 2 & Guo et al. [39], Guo et al. [40] & 2 \\
\hline & 3 & Korchagin et al.,[42] & 1 \\
\hline \multirow{3}{*}{ IoT } & 1 & $\begin{array}{l}\text { Druout et al. [38], Ismail et al. [31], Liu and Yu [63], Reis et al. [77], } \\
\text { Santonino et al. [83], Wang et al. [36] }\end{array}$ & 6 \\
\hline & 2 & Guo et al. [39], Guo et al. [40], Liang et al. [45] & 3 \\
\hline & 3 & Korchagin et al. [42] & 1 \\
\hline \multirow{3}{*}{ Robots } & 1 & Druout et al. [38], Greco et al. [57], Song et al. [37] & 3 \\
\hline & 2 & $\begin{array}{l}\text { Guo et al. [39], Kheddar et al. [61], Luxenburger et al. [43], Pérez et al. } \\
{[75], \text { Xin et al. [47], Zhang et al. [48] }}\end{array}$ & 6 \\
\hline & 3 & Barbosa et al. [51], Nunes and Barbosa [72] & 2 \\
\hline \multirow{3}{*}{ Simulation } & 1 & $\begin{array}{l}\text { Bécue et al. [52], Bolotov et al. [53], Caggiano and Teti [55], Cao et al. } \\
\text { [56], Mandolla et al. [66], Manohar et al. [67], Seon et al. [84], Tao and } \\
\text { Qi [44] }\end{array}$ & 8 \\
\hline & 2 & $\begin{array}{l}\text { Guo et al. [39], Liang et al. [45], Xin et al. [47], Xu et al. [87], Zhang } \\
\text { and Zhu [13], Zhang et al. [48], Zhang et al. [49] }\end{array}$ & 7 \\
\hline & 3 & $\begin{array}{l}\text { Jia et al. [35], Ríos et al. [79], Liu et al. [62], Cai et al. [14], } \\
\text { Korchagin et al. [42] }\end{array}$ & 5 \\
\hline \multirow{3}{*}{$\begin{array}{l}\text { Sist. } \\
\text { Integration }\end{array}$} & 1 & Druout et al. [38], Mas et al. [69] & 2 \\
\hline & 2 & Guo et al. [39], Guo et al. [40], Liang et al. [45] & 3 \\
\hline & 3 & Jia et al. [35], Korchagin et al. [42] & 2 \\
\hline
\end{tabular}

Source: Developed by the authors

\section{Results analysis}

The review of technical literature presented the distribution of publications in I4.0 technologies as depicted by Fig. 3.

The simulation, AR, and Big Data technologies lead the number of publications. It shows again, an evolution of digital tools used in the aircraft manufacturing processes, specially dealing with the creation of digital-twins. These kinds of tools incorporate a combination of real and virtual worlds, real-time interaction, and accurate 3D registration of virtual and real objects. It favors the gains of productivity and quality when digital tools are used before the technology implementation on the shop floor, providing an evaluation in a virtual environment.
Table 4 presents an analysis of the research papers dealing with multiple I4.0 technologies in an integrated manner. In this case, Big Data, IoT, and simulation techniques showed to be often explored together for applications in the aviation industry. This trend is compatible with the idea of developing data-based systems that take advantage of multiple sensors monitoring many fabrication processes to develop and update a digital model of the shop-floor. Also, Big Data algorithms, as well as machine learning techniques showed promising applications to optimize production with information that can be extracted from large databases available in this environment.

Figure 4 shows the number of papers published in each year from 2011 onwards. It can be noted a significant 


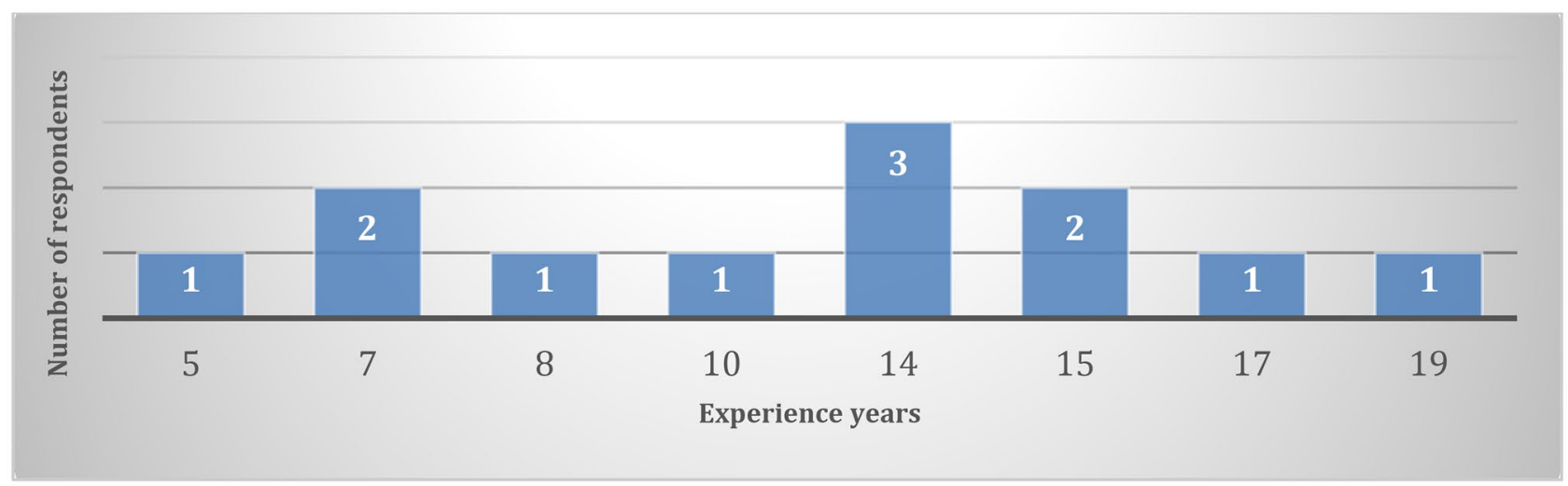

Fig. 6 Specialists' years of experience in the aircraft manufacturing sector

increase in publications between the years 2017 to 2019 . The year 2020 showed a drop that can be explained by the coronavirus pandemic, which negatively impacted both the aeronautical and academic sectors.

The evolution (peak of 2017-2019) showed above can be explained by the initiatives to use digital technologies for increase of productivity, repeatability, and standardization, in addition to innovation of processes.

Based on the nine I4.0 technologies mentioned and highlighted above by BCG, Fig. 5 presents the classification of the published papers into 3 levels of maturity: assessment proving, pre-production, and production implementation.

Strategically analyzing and understanding the conditions for implementing new technologies has always been the focus of the aircraft industry. Regarding I4.0 technologies, understanding the advances and their maturity and readiness are crucial factors for increasing the competitive edge in this sector. In the academic dimension, the publication of studies that provide technological details of aeronautical companies are rare, because they involve issues of confidentiality. Thus, the data obtained for the analysis of technological maturity, in addition to academic papers, also consider publications obtained directly from the manufacturers' Web sites, materials obtained at conferences and congresses.
The analysis and proof-of-concept related to a technology to be implemented in the aircraft manufacturing sector has high requirements for certification. This branch of the industry requires some specific standards that must be followed to guarantee the production processes, product features and also, the extreme operational safety. Thus, even being the origin of several technologies already implemented in other productive sectors, it is noted that the aircraft industry segment sometimes spends more time than others, because of the severity, restrictions and rules demanded by regulatory agencies.

In this sense, the classification observed in Fig. 5 emphasizes that most of the I4.0 technologies mentioned in papers are within the assessment proving level. It shows a relevant initiative of research in this industrial sector that represents many proof-of-concepts evaluations on the way, in order to leverage the technologies maturity to be applied in the production environment. Another important point to be highlighted is the number of mentions of Simulation technology, which shows a growth of virtual applications for the increase of digitization in the manufacturing processes. Table 5 also illustrates the references classified according the I4.0 technologies developed in the research as well as with the respective TRL Phase applied according to what was previously presented in Table 3.
Fig. 7 Readiness level of I4.0 technologies on aircraft manufacturing according to specialists

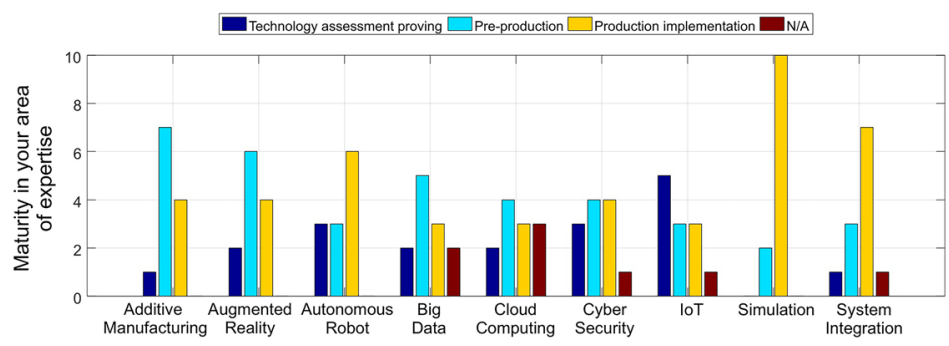




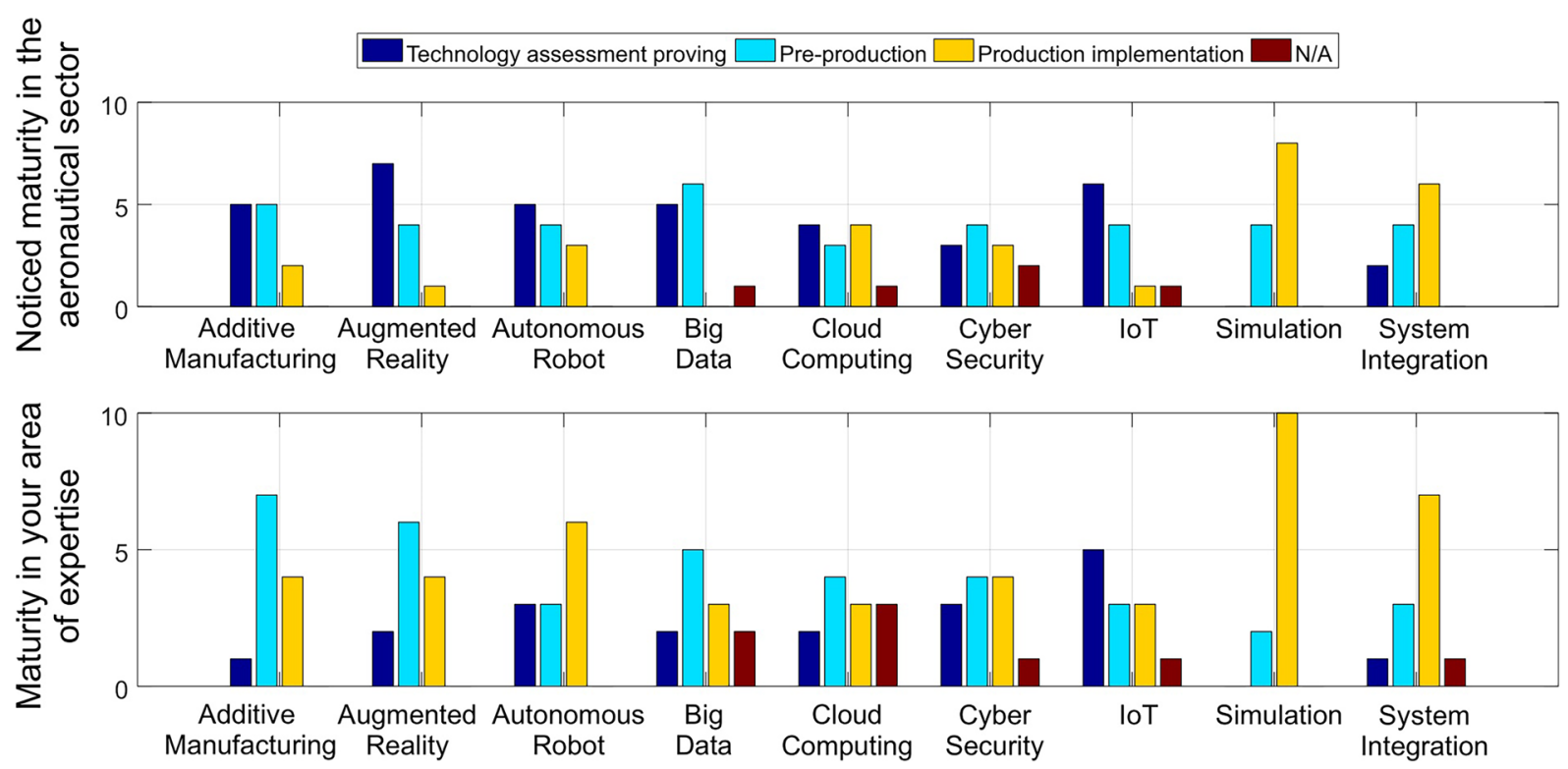

Fig. 8 Comparison of perceived maturity in the aeronautical segment and in the area of expertise of the specialists

\section{Survey with specialists}

For a comparative assessment, experts from the aircraft manufacturing sector were consulted on practical applications in this branch of the industry. The application of this research aimed to capture and compare the maturity perceived by them in the world aeronautical segment and in their areas of expertise. A total of 12 experts from 5 different companies around the world responded to the survey. Since the sample size of the research is small, it is important to note that it the conclusions can be biased to the view of these specialists. Despite of that, a rough trend on the results can be compared to the literature review in order to observe if the perceived maturity of the I4.0 technologies in the aircraft industry agrees with the academic research.
Figure 6 indicates the years of experience of each specialist in the aeronautical segment. With the results of this survey, we also seek to understand and compare the maturity of technologies obtained in the literature, already discussed in Sect. 4 of this paper.

For this survey, a questionnaire was elaborated (see Appendix), and its application was carried out, using a platform of questions and to store the answers. The application platform used was Google Forms, responsible for organizing questionnaires and their answers, being possible to analyze them jointly or individually.

For the treatment of data, the content analysis methodology was used, due to the answers of the interviews are documented. It can provide the analysis techniques to obtain
Table 6 Summary of the results of the survey considering the mode of the perceived maturity

\begin{tabular}{|c|c|c|}
\hline I4.0 technology & Perceived maturity (overall) & Perceived maturity (area of expertise) \\
\hline Additive manufacturing & Pre-production (58\%) & $\begin{array}{l}\text { Technology assessment proving } \\
(42 \%) / \text { Pre-production }(42 \%)\end{array}$ \\
\hline Augmented reality & Pre-production (50\%) & Technology assessment proving (58\%) \\
\hline Autonomous robot & Production implementation (50\%) & Technology assessment proving $(42 \%)$ \\
\hline Big Data & Pre-production (42\%) & Pre-production (50\%) \\
\hline Cloud computing & Pre-production (33\%) & $\begin{array}{l}\text { Technology assessment proving } \\
(33 \%) / \text { Production implementation } \\
(33 \%)\end{array}$ \\
\hline Cyber security & $\begin{array}{l}\text { Pre-production (33\%)/Production } \\
\text { implementation }(33 \%)\end{array}$ & Pre-production (33\%) \\
\hline IoT & Technology assessment proving ( $42 \%)$ & Technology assessment proving (50\%) \\
\hline Simulation & Production implementation (83\%) & Production implementation (67\%) \\
\hline System integration & Production implementation (58\%) & Production implementation (50\%) \\
\hline
\end{tabular}


the indicators that allow the inference of knowledge related to the theme.

The research was qualitative and quantitative, seeking to understand the reality of the readiness level of I4.0 technologies on aircraft manufacturing sector, based on the background of practitioners of this field. Thus, it is understood that the results are a reliable illustration of empiric scenario of companies that builds aircrafts. Thus, the results are presented in Fig. 7.

Figure 7 indicates that most I4.0 technologies are preproduction maturity, which seems to make sense given the overall maturity of the I 4.0 concepts. On the other hand, the technologies with the highest maturity levels are autonomous robots, simulation, and systems integration. According to specialists, these technologies have already been used an implemented in aircraft industries (Fig. 8). As reported in the results of the papers (Fig. 3), the IoT technology is the one with the lowest maturity in the aircraft industry.

Table 6 summarizes the most frequent perceived maturity during the survey with the specialists with the percentage of answers. Due to the small sample size of the research, the perceived maturity of a few I4.0 technologies are not clear.

Comparing the maturity perceived in the aeronautical segment with the maturity in areas of specialist's expertise (Table 6), there is a convergence in the simulation and systems integration technologies, both with high maturity. The maturity of IoT technology also converges as one of the smallest in the segment. The biggest divergence is observed in the additive manufacturing technology where, in the area of expertise of the specialists, it was immature. It can be inferred that this is a specific result of the companies evaluated, not reflecting the general context of the segment.

\section{Conclusions}

This paper has highlighted a recent literature review about the interrelationship among I4.0 technologies, TRL, and aircraft manufacturing. For this purpose, a literature review has been conducted to enable the identification of related articles of interest and a novel literature classification. Grouping criterion has been used to construct the classification, which has provided the connection between I4.0 technologies and its readiness maturity level when applied to the aircraft manufacturing industry.
The description and analysis of the findings of the individual lines have allowed to understand the state of these research themes, in order to evaluate the applications of I4.0 technologies according to assessment proving, pre-production and implemented levels. It brings a broad and modern overview of the state-of-the-art for researchers, managers, and practitioners of the aircraft industry who has interest to find out about this role, if they are novices or seeking to dig deeper into the matter. In addition, the survey with specialists was intended to complement the scientific review, based on the practical experience and background of skilled professionals of the field.

Thus, this paper provides specific knowledge of the most researched aspects, the gaps that exist, and directions for possible future research and assistance for the industry. Also, it's important to emphasize that the research still needs to be continued about the use of emerging I4.0 technologies inside the aircraft manufacturing sector, due the potential of new developments and specific applications for this branch of industry.

\section{Appendix}

I4.0- technologies maturity in aircraft manufacturing

- Considering the 9 main technologies of industry 4.0, answer the questions as requested.

- Use the legends as reference.

1. Name

2. How long have you been in the aeronautical sector?

3. What is your area of expertise in the aeronautical segment? (e.g., production, engineering, logistics)

Use this legend to answer the questions below 


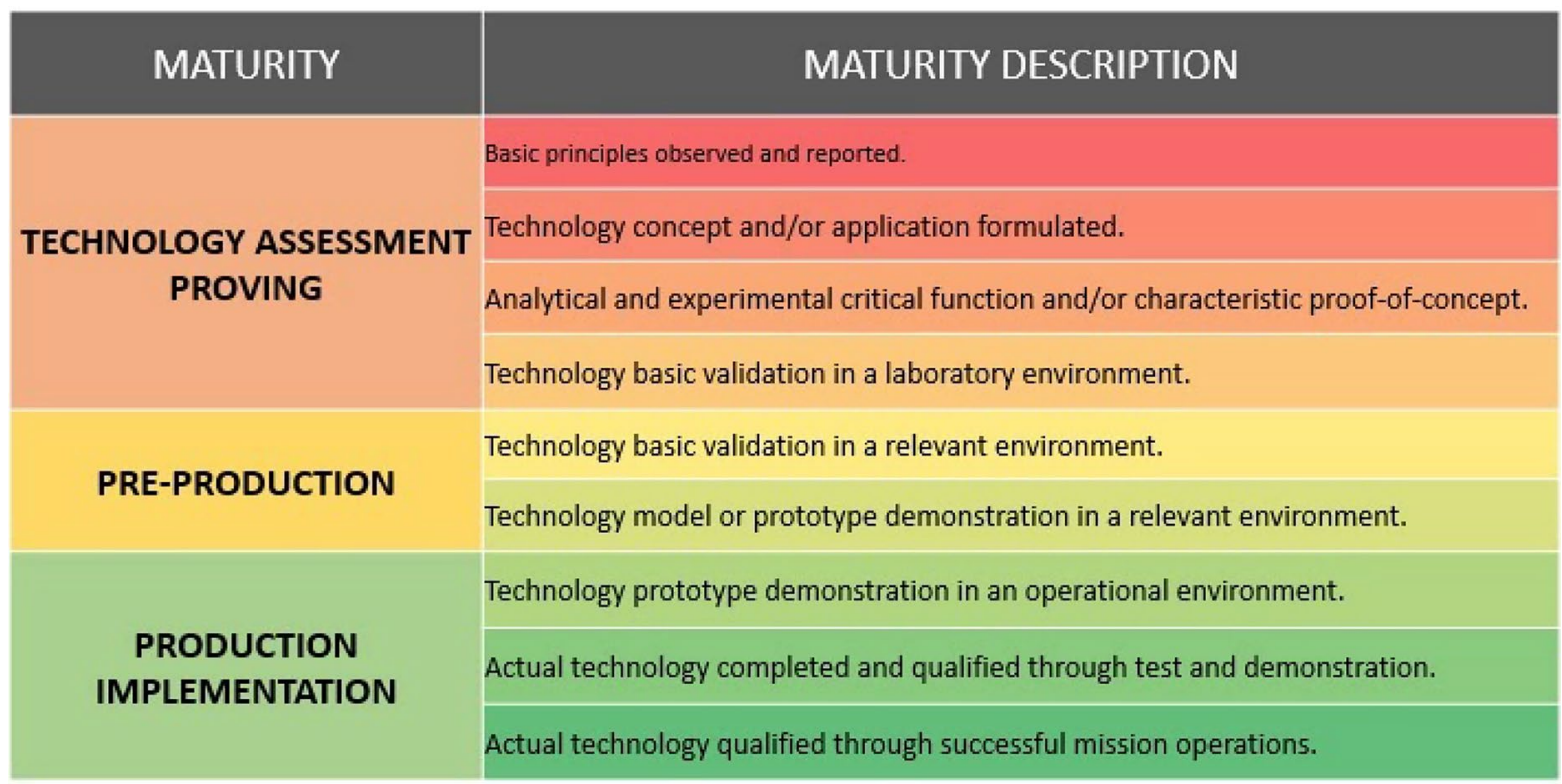

4. Noticed maturity in the aeronautical sector *

Considering your knowledge in the aeronautical sector, classify the technologies according to maturity. If you do not have an application, select the option that is not applicable (N/A).

\begin{tabular}{|c|c|c|c|c|}
\hline & $\begin{array}{c}\text { TECHNOLOGY } \\
\text { ASSESSMENT } \\
\text { PROVING }\end{array}$ & $\begin{array}{c}\text { PRE- } \\
\text { PRODUCTION }\end{array}$ & $\begin{array}{c}\text { PRODUCTION } \\
\text { IMPLEMENTATION }\end{array}$ & $\mathrm{N} / \mathrm{A}$ \\
\hline $\begin{array}{l}\text { Additive } \\
\text { Manufacturing }\end{array}$ & & & & \\
\hline $\begin{array}{l}\text { Augment } \\
\text { Reality }\end{array}$ & & & & \\
\hline $\begin{array}{l}\text { Autonomous } \\
\text { Robot }\end{array}$ & & & & \\
\hline Big Data & & & & \\
\hline $\begin{array}{l}\text { Cloud } \\
\text { Computing }\end{array}$ & & & & \\
\hline Cyber Security & & & & \\
\hline IOT & & & & \\
\hline Simulation & & & & \\
\hline $\begin{array}{l}\text { System } \\
\text { integration }\end{array}$ & & & & \\
\hline
\end{tabular}


5. Maturity in your area of expertise *

Considering your area of expertise, classify the technologies according to maturity. If you do not have an application, select the option N/A

\section{TECHNOLOGY \\ ASSESSMENT \\ PROVING}

Acknowledgements The second author would like to thank the National Council for Scientific and Technological Development (CNPq) for his technological productivity fellowship (process 314516/20182) and also the Sao Paulo Research Foundation (FAPESP) for Grant \#2019/22115-0.

Author contribution All author(s) contributed to the construction of the paper as follows: Gabriel: literature review, conception of strings and writing; Gustavo: idealization of the paper, technical evaluation and writing; Pedro: creation of statistics, graphics and writing; Eduardo: application of survey, revision and writing. Frederico: review of the paper and assistance to survey; Sidney: literature review, creation of tables and writing.

Availability of data and materials All information, figures, and tables are in the manuscript. It will not be necessary to provide other data and materials.

\section{Declarations}

Ethical approval The author(s) declare that the article was constructed respecting all ethical conditions of publication.
Consent to participate All author(s) participated in the preparation of the article. In this way, the authors allow their names to be in the article.

Consent to publish Authors allow publication. All rights will belong to the journal.

Conflict of interest The authors declare no competing interests.

\section{References}

1. Brodzik C, Lamar K, Shaikh A (2020) Deloitte Insights. Tech Trends 2020. https://www2.deloitte.com/us/en/insights/focus/ tech-trends.html. Accessed 2 Sept 2021

2. Hooi LW, Leong TY (2017) Total productive maintenance and manufacturing performance improvement. J Qual Maint Eng 23(1):2-21

3. Chen T, Tsai HR (2017) Ubiquitous manufacturing: current practices, challenges, and opportunities. Robot Comput Integr Manuf 45:126-132. https://doi.org/10.1016/j.rcim.2016.01.001 
4. Martin C, Leurent H (2017) Technology and innovation for the future of production: Accelerating value creation. World Economic Forum, Geneva, p 1-38. https://www.weforum.org/. Accessed 2 Sept 2021

5. Ganzarain J, Errasti N (2016) Three stage maturity model in SME's towards industry 4.0. J Ind Eng Manag 9(5):1119-1128. https://doi.org/10.3926/jiem.2073

6. Tasmin $\mathrm{R}$ et al (2020) The readiness of automotive manufacturing company on Industrial 4.0 towards quality performance. Int J Integr Eng 12(7):160-172. https://doi.org/10.30880/ijie.2020.12. 07.018

7. Haddara M, Elragal A (2015) The readiness of ERP systems for the factory of the future. Proc Comput Sci 64:721-728. https:// doi.org/10.1016/j.procs.2015.08.598

8. Benias N, Markopoulos AP (2017) A review on the readiness level and cyber-security challenges in Industry 4.0. In: South-East Europe Design Automation, Computer Engineering, Computer Networks and Social Media Conference, SEEDA-CECNSM 2017. https://doi.org/10.23919/SEEDA-CECNSM.2017.8088234

9. Frigo MA, da Silva ECC, Barbosa GF (2016) Augmented reality in aerospace manufacturing: a review. J Ind Intell Inf 4(2):125130. https://doi.org/10.18178/jiii.4.2.125-130

10. Ferreira MJB et al (2009) Relatório de Acompanhamento Setorial Indústria Aeronáutica. Agência Brasileira de Desenvolvimento Industrial - ABDI e o Núcleo de Economia Industrial e da Tecnologia do Instituto de Economia da Universidade Estadual de Campinas - Unicamp. Volume IV, Dezembro de 2009.

11. Seitz F, Steele LW (1985) The Competitive Status of the U.S. Civil Aviation Manufacturing Industry: A Study of the Influences of Technology in Determining International Industrial Competitive Advantage. The National Academies Press, Washington, DC. https://doi.org/10.17226/641

12. Arnaldo Valdes R, Gómez Comendador VF (2018) Aviation 4.0: More safety through automation and digitization. WIT Trans Built Environ 174:225-236. https://doi.org/10.2495/SAFE170211

13. Zhang X, Zhu W (2019) Application framework of digital twin-driven product smart manufacturing system: A case study of aeroengine blade manufacturing. Int J Adv Robot Syst 16(5):1729881419880663. https://doi.org/10.1177/1729881419880663

14. Cai H, Zhang W, Zhu Z (2019) Quality management and analysis of aircraft final assembly based on digital twin. In: 2019 11th International Conference on Intelligent Human-Machine Systems and Cybernetics (IHMSC 2019), vol 1, p 202-205. https://doi.org/ 10.1109/IHMSC.2019.00054

15. de Weck OL, Reed D (2014) Trends in advanced manufacturing technology innovation. In: Locke RM, Wellhausen RL (eds) Production in the Innovation Economy. MIT Press, Cambridge, pp 235-262. https:// doi.org/10.7551/mitpress/9780262019927.003.0009

16. Zhou J (2013) Digitalization and intelligentization of manufacturing industry. Adv Manuf 1(1):1-7. https://doi.org/10.1007/ s40436-013-0006-5

17. Lewis D (2019) Aerospace 4.0 - why we need it. https://www.aeromag.com/aerospace-4-0-why-we-need-it/. Accessed 2 Apr 2021

18. Guyon I et al (2019) Analysis of the opportunities of industry 4.0 in the aeronautical sector. In: Centre for Robotics, MINES ParisTech, PSL Research University, 60 bd. Saint-Michel, Paris, 75006, France: International Institute of Informatics and Systemics, IIIS, p 62-67. https://www.scopus.com/inward/record.uri? eid $=2$-s2.0-85066029548\&partnerID $=40 \& \mathrm{md} 5=1 \mathrm{f} 3 \mathrm{a} 58 \mathrm{f} 46 \mathrm{~d}$ $46 c a 50 d 2205 c 67 b 055 a a 95$. Accessed 5 Oct 2021

19. Straub J (2015) In search of technology readiness level (TRL) 10. Aerosp Sci Technol 46:312-320. https://doi.org/10.1016/j.ast.2015.07.007

20. Lasi H, Fettke P, Kemper HG, Feld T, Hoffmann M (2014) Industry 4.0. Bus Inf Syst Eng 6(4):239-242
21. Büchi G, Cugno M, Castagnoli R (2020) Smart factory performance and Industry 4.0. Technol Forecast Soc Change 150:119790. https://doi.org/10.1016/j.techfore.2019.119790

22. Lu Y (2017) Industry 4.0: A survey on technologies, applications and open research issues. J Ind Inf Integr 6:1-10

23. Vaidya S, Ambad P, Bhosle S (2018) Industry 4.0 - A Glimpse. Proc Manuf 20:233-238. https://doi.org/10.1016/j.promfg.2018. 02.034

24. Núñez-Merino M et al (2020) Information and digital technologies of Industry 4.0 and Lean supply chain management: a systematic literature review. Int J Prod Res 58(16):5034-5061. https://doi.org/ $10.1080 / 00207543.2020 .1743896$

25. Stock T, Seliger G (2016) Opportunities of sustainable manufacturing in industry 4.0. Procedia CIRP 40:536-541

26. Zhong RY, Xu X, Klotz E, Newman ST (2017) Intelligent manufacturing in the context of industry 4.0: a review. Engineering 3(5):616-630

27. Neil SP, Hashemi MR (2018) Technology Readiness Level Calculator.White Paper: Air Force Research Laboratory2004 (December 2016), pp 1-16

28. Héder M (2017) 'From NASA to EU: the evolution of the TRL scale in Public Sector Innovation. Innov J 22(2):1-23

29. Mankins JC (1995) Technology Readiness Levels White Paper 51(1):51

30. Lemos JC, Chagas MF (2016) Application of maturity assessment tools in the innovation process: converting system's emergent properties into technological knowledge. RAI Revista de Administração e Inovação 13(2):145-153. https://doi.org/10.1016/j.rai.2015.08.001

31. Ma F et al (2016) The review of manufacturing technology for aircraft structural part. Proc CIRP 56:594-598. https://doi.org/ 10.1016/j.procir.2016.10.117

32. Ceruti A et al (2019) Maintenance in aeronautics in an Industry 4.0 context: the role of augmented reality and additive manufacturing. J Comput Des Eng 6(4):516-526. https://doi.org/10.1016/j. jcde.2019.02.001

33. Bueno A, Godinho Filho M, Frank AG (2020) Smart production planning and control in the Industry 4.0 context: a systematic literature review. Comput Ind Eng 149:106774. https://doi.org/ 10.1016/j.cie.2020.106774

34. Moher D et al (2009) Preferred reporting items for systematic reviews and meta-analyses: The PRISMA statement. PLoS Med 6(7):e1000097. https://doi.org/10.1371/journal.pmed.1000097

35. Jia X, Geng J, Huang L (2011) Research on PLM-oriented collaboration digital process planning technology. In: Han JT, Jiang ZY, Jiao S (eds) Advanced Manufacturing Technology pts 1 and 2, vol 156-157. Trans Tech Publications Ltd, Zurich, pp 694-699. https://doi.org/10.4028/www.scientific.net/AMR.156-157.694

36. Wang C, Bi Z, Daxu L (2014) IoT and cloud computing in automation of assembly modeling systems. IEEE Trans Ind Inform 10(2):1426-1434. https://doi.org/10.1109/TII.2014.2300346

37. Song T, Xi F, Guo S, Ming Z, Lin Y (2015) A comparison study of algorithms for surface normal determination based on point cloud data. Precis Eng 39:47-55. https://doi.org/10.1016/j.preci sioneng.2014.07.005

38. Drouot A, Zhao R, Irving L, Ratchev S (2019) Towards industry 4.0: the future automated aircraft assembly demonstrator. IFIP Adv Inf Commun Technol 530:169-182. https://doi.org/10.1007/ 978-3-030-05931-6_16

39. Guo F, Zou F, Liu J, Wang Z (2018) Working mode in aircraft manufacturing based on digital coordination model. Int J Adv Manuf Technol 98(5-8):1547-1571. https://doi.org/10.1007/ s00170-018-2048-0

40. Guo Z, Zhang Y, Zhao X, Song X (2020) CPS-based self-adaptive collaborative control for smart production-logistics systems. IEEE Trans Cybernet 51(1):188-198 
41. Ismail MS, Chan YP, Hussain MI, Muhammad N, Zain ZM (2019). A new approach of temperature and humidity alert system at composite panel manufacturing area. In: AIP Conference Proceedings, 2129(July). https://doi.org/10.1063/1.5118013

42. Korchagin A, Deniskina A, Fateeva I (2019) Lean and energy efficient production based on internet of things (IOT) in aviation industry. E3S Web Conf 110:1-13. https://doi.org/10.1051/e3sconf/ 201911002124

43. Luxenburger A, Mohr J, Spieldenner T, Merkel D, Espinosa F, Schwartz T, Reinicke F, Ahlers J, Stoyke M (2019) Augmented reality for human-robot cooperation in aircraft assembly. In: 2019 IEEE International Conference On Artificial Intelligence And Virtual Reality (AIVR), p 263-266. https://doi.org/10.1109/AIVR46125.2019. 00061

44. Tao F, Qi Q (2019) Make more digital twins. Nature 573(7775):490-491. https://doi.org/10.1038/d41586-019-02849-1

45. Liang B, Liu W, Liu K, Zhou M, Zhang Y, Jia Z (2020) A displacement field perception method for component digital twin in aircraft assembly. Sensors 20(18):5161. https://doi.org/10.3390/ s20185161

46. Miller J, Hoover M, Winer E (2020) Mitigation of the Microsoft HoloLens' hardware limitations for a controlled product assembly process. Int J Adv Manuf Technol 109(5-6):1741-1754. https:// doi.org/10.1007/s00170-020-05768-y

47. Xin Y, Yang S, Wang G, Evans R, Wu F (2020) A tool path optimization approach based on blend feature simplification for multi-cavity machining of complex parts. Sci Prog 103(1):0036850419874233. https://doi.org/10.1177/0036850419874233

48. Zhang H, Yan Q, Wen Z (2020) Information modeling for cyberphysical production system based on digital twin and AutomationML. Int J Adv Manuf Technol 107(3-4):1927-1945. https:// doi.org/10.1007/s00170-020-05056-9

49. Zhang Z, Guan Z, Gong Y, Luo D, Yue L (2020) Improved multifidelity simulation-based optimisation: application in a digital twin shop floor. Int J Prod Res. https://doi.org/10.1080/00207543.2020. 1849846

50. AIRBUS (2019) How Airbus data analytic platform is helping to solve the aviation data challenge. MRO Aviation Okinawa, January, 2019.

51. Barbosa GF, Shiki SB, Savazzi JO (2019) Digitalization of a standard robot arm toward 4th industrial revolution. Int J Adv Manuf Technol 105(5-6):2707-2720. https://doi.org/10.1007/s00170-019-04523-2

52. Bécue A, Maia E, Feeken L, Borchers P, Praça I (2020) A new concept of digital twin supporting optimization and resilience of factories of the future. Appl Sci 10(13):4482. https://doi.org/10. 3390/app10134482

53. Bolotov MA, Pechenin VA, Ruzanov NV, Grachev IA (2019) Information model and software architecture for the implementation of the digital twin of the turbine rotor. J Phys Conf Ser 1368(5):052013. https://doi.org/10.1088/1742-6596/1368/5/052013

54. Bottani E, Vignali G (2019) Augmented reality technology in the manufacturing industry: A review of the last decade. IISE Trans 51(3):284-310. https://doi.org/10.1080/24725854.2018.1493244

55. Caggiano A, Teti R (2018) Digital factory technologies for robotic automation and enhanced manufacturing cell design. Cogent Eng 5(1):1426676. https://doi.org/10.1080/23311916.2018.1426676

56. Cao X, Zhao G, Xiao W (2020) Digital Twin-oriented real-time cutting simulation for intelligent computer numerical control machining. Proc Inst Mech Eng B J Eng Manuf. https://doi.org/ $10.1177 / 0954405420937869$

57. Greco A, Caputo F, Caterino M, D'Ambra S, Fera M, Laudante E (2020) Composite parts assembly operational improvements. Macromol Symp 389(1):1900098. https://doi.org/10.1002/masy. 201900098

58. Gupta RK, Belkadi F, Buergy C, Bitte F, Da Cunha C, Buergin J, Lanza G, Bernard A (2018) Gathering, evaluating and managing customer feedback during aircraft production. Comput Ind Eng 115:559-572. https://doi.org/10.1016/j.cie.2017.12.012

59. Khajavi HS, Holmström J, Partanen J (2018) Additive manufacturing in the spare parts supply chain: hub configuration and technology maturity. Rapid Prototyp J 24(7):1178-1192. https://doi.org/ 10.1108/RPJ-03-2017-0052

60. Jenett B, Cramer N, Swei S, Cheung K (2019) Design approximation and proof test methods for a cellular material structure. In: AIAA Scitech 2019 Forum. https://doi.org/10.2514/6.2019-1861

61. Kheddar A, Caron S, Gergondet P, Tanguy A, Ott C, Henze B, Mesesan G, Englsberger J, Roa M, Kheddar A, Caron S, Gergondet P, Comport A, Tanguy A, Kheddar A, Gergondet P, Comport A, Tanguy A, Ott C, Kanehiro F (2019) Humanoid robots in aircraft manufacturing: the airbus use cases. IEEE Robot Autom Mag 26(4):30-45

62. Liu C, Wu H, Yang Y, Wang J (2017) A rapid and intelligent approach to design forming shape model for precise manufacturing of flanged part. Int J Adv Manuf Technol 91(9-12):31213134. https://doi.org/10.1007/s00170-016-9935-z

63. Liu J, Yu J (2013) Research on the framework of internet of things in manufacturing for aircraft large components assembly site. In: Proceedings - 2013 IEEE International Conference on Green Computing and Communications and IEEE Internet of Things and IEEE Cyber, Physical and Social Computing, GreenComIThings-CPSCom 2013, p 1192-1196. https://doi.org/10.1109/ GreenCom-iThings-CPSCom.2013.207

64. Lv X (2020) Overall framework design of integrated manufacturing center of underground laser rapid prototyping for aeroengine components based on cloud computing and internet of things. J Phys Conf Ser 1624(6):062009. https://doi.org/10.1088/17426596/1624/6/062009

65. Manda VR, Kampurath V, Mrk C (2018) 3D printing and its effect on outsourcing: a study of the Indian aircraft industry. J Aerosp Technol Manag 10:862. https://doi.org/10.5028/jatm.v10.862

66. Mandolla C, Petruzzelli AM, Percoco G, Urbinati A (2019) Building a digital twin for additive manufacturing through the exploitation of blockchain: A case analysis of the aircraft industry. Comput Ind 109:134-152. https://doi.org/10.1016/j.compind.2019.04. 011

67. Manohar K, Hogan T, Buttrick J, Banerjee AG, Kutz JN, Brunton SL (2018) Predicting shim gaps in aircraft assembly with machine learning and sparse sensing. J Manuf Syst 48:87-95. https://doi. org/10.1016/j.jmsy.2018.01.011

68. Marzano A, Friel I, Erkoyuncu JA, Court S (2015) Design of a virtual reality framework for maintainability and assemblability test of complex systems. In: Erkoyuncu J (ed) CIRPE 2015 Understanding the Life Cycle Implications of Manufacturing, vol 37. Elsevier, Amsterdam, pp 242-247. https://doi.org/10.1016/j. procir.2015.08.067

69. Mas F, Oliva M, Rios J, Gomez A, Olmos V, Garcia JA (2015) PLM based approach to the industrialization of aeronautical assemblies. In: Canela JM, Corral IB (eds) Mesic Manufacturing Engineering Society International Conference 2015, vol 132. Elsevier, Amsterdam, pp 1045-1052. https://doi.org/10.1016/j. proeng.2015.12.594

70. Mayrhofer W, Rupprecht P, Schlund S (2019) One-fits-all vs. tailormade: user-centered workstations for field assembly with an application in aircraft parts manufacturing. Proc Manuf 39:149-157. https://doi.org/10.1016/j.promfg.2020.01.287

71. Najmon JC, Raeisi S, Tovar A (2019) Review of additive manufacturing technologies and applications in the aerospace industry. In: Froes F, Boyer R (eds) Additive Manufacturing for the Aerospace Industry. Elsevier Inc, Amsterdam, pp 7-31. https://doi.org/10. 1016/B978-0-12-814062-8.00002-9

72. Nunes VA, Barbosa GF (2020) Simulation-based analysis of AGV workload used on aircraft manufacturing system: a theoretical 
approach. Acta Sci Technol 42(1):e47034. https://doi.org/10.4025/ actascitechnol.v42i1.47034

73. Ottogalli K, Rosquete D, Amundarain A, Aguinaga I, Borro D (2019) Flexible Framework to Model Industry 4.0 Processes for Virtual Simulators. Appl Sci 9(23):4983. https://doi.org/10.3390/ app9234983

74. Ou P (2012) Maintenance Applications of Augmented Reality for The Chinese Aerospace Industry. In: School of Applied Science MSc, vol 66

75. Pérez L, Rodríguez-Jiménez S, Rodríguez N, Usamentiaga R, García DF, Wang L (2020) Symbiotic human-robot collaborative approach for increased productivity and enhanced safety in the aerospace manufacturing industry. Int $\mathrm{J}$ Adv Manuf Technol 106(3-4):851-863. https://doi.org/10.1007/s00170-019-04638-6

76. Regenbrecht H, Baratoff G, Wilke W (2005) Augmented reality projects in the automotive and aerospace industries. IEEE Comput Graph Appl 25(6):48-56. https://doi.org/10.1109/MCG.2005.124

77. Reis R, Diniz F, Mizioka L, Olivio P, Lemos G, Quintiães M, Menezes R, Amadio F, Caldas N (2018) FASTEN: An IoT platform for manufacturing. Embraer use case MATEC Web Conf 233:1-8. https://doi.org/10.1051/matecconf/201823300009

78. Rice M, Tay HH, Ng J, Lim C, Selvaraj SK, Wu E (2015) Augmented wire routing navigation for wire assembly. In: Proceedings of the 2015 IEEE International Symposium on Mixed and Augmented Reality, ISMAR 2015, p 88-91. https://doi.org/10. 1109/ISMAR.2015.28

79. Ríos J, Morate FM, Oliva M, Hernández JC (2016) Framework to support the aircraft digital counterpart concept with an industrial design view. Int J Agile Syst Manag 9(3):212-231. https://doi.org/ 10.1504/IJASM.2016.079934

80. Romero A, Vieira DR (2016) How additive manufacturing improves product lifecycle management and supply chain management in the aviation sector? In: Bouras A, Eynard B, Foufou S, Thoben KD (eds) Product Lifecycle Management in the Era of Internet of Things PLM 2015, vol 467. Springer, Cham, pp 74-85. https://doi.org/10.1007/978-3-319-33111-9_8
81. Ruiz L, Torres M, Gómez A, Díaz S, González JM, Cavas F (2020) Detection and classification of aircraft fixation elements during manufacturing processes using a convolutional neural network. Appl Sci 10(19):1-13. https://doi.org/10.3390/app10 196856

82. Safi M, Chung J, Pradhan P (2019) Review of augmented reality in aerospace industry. Aircr Eng Aerosp Technol 91(9):1187-1194. https://doi.org/10.1108/AEAT-09-2018-0241

83. Santonino MD, Koursaris CM, Williams MJ (2018) Modernizing the supply chain of Airbus by integrating RFID and Blockchain processes. Int J Aviat Aeronaut Aerosp 5(4):4. https://doi.org/10. 15394/ijaaa.2018.1265

84. Seon G, Nikishkov Y, Makeev A, Ferguson L (2020) Towards a digital twin for mitigating void formation during debulking of autoclave composite parts. Eng Fract Mech 225:106792. https:// doi.org/10.1016/j.engfracmech.2019.106792

85. Um J, Choi Y-C, Stroud I (2014) Factory planning system considering energy-efficient process under cloud manufacturing. In ElMaraghy $\mathrm{H}$ (ed) Variety Management in Manufacturing: Proceedings of the 47th CIRP Conference on Manufacturing Systems, vol 17. Elsevier, Amsterdam, p 553-558. https://doi.org/10.1016/j. procir.2014.01.084

86. Xia R, Zhao J, Zhang T, Su R, Chen Y, Fu S (2020) Detection method of manufacturing defects on aircraft surface based on fringe projection. Optik 208:164332. https://doi.org/10.1016/j. ijleo.2020.164332

87. Xu Z, Ji F, Ding S, Zhao Y, Zhou Y, Zhang Q, Du F (2020) Digital twin-driven optimization of gas exchange system of 2-stroke heavy fuel aircraft engine. J Manuf Syst 58:132-145. https://doi. org/10.1016/j.jmsy.2020.08.002

Publisher's Note Springer Nature remains neutral with regard to jurisdictional claims in published maps and institutional affiliations. 